\title{
Advocating for growers as SGMA moves forward
}

\author{
An interview with Christina Beckstead, Executive Director, Madera County Farm Bureau
}

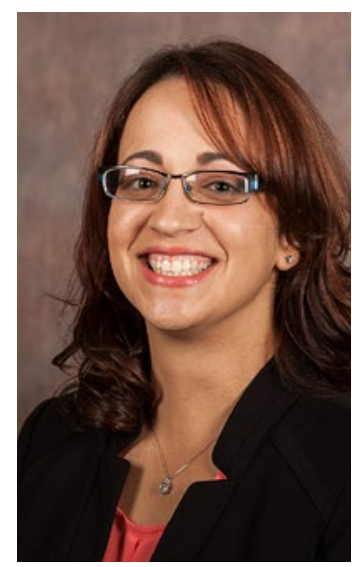

Christina Beckstead
Groundwater basins and water and irrigation districts in Madera County. Irrigated areas outside of water district or irrigation district service areas are shown in white and depend entirely on groundwater. Madera County is unique in that all such areas are part of a countymanaged groundwater sustinability agency. Map source: Madera County groundwater sustainability agencies.
C hristina Beckstead is executive director of Madera County Farm Bureau. As an advocate for growers in her county, she has been closely involved in the formation of groundwater sustainability agencies (GSAs) in Madera County and the steps towards the development of groundwater sustainability plans (GSPs). There are three subbasins in Madera County - the Madera subbasin, the Chowchilla subbasin and a small portion of the Delta-Mendota subbasin. All are classified by the state as critically overdrafted.

\section{Tell us about the groundwater landscape in Madera County and where things stand with SGMA implementation.}

The Madera subbasin has just under 400,000 irrigated acres, about half of which is supplied with surface water by irrigation or water districts. Each of the districts and municipalities has formed a GSA, creating seven GSAs with boundaries roughly matching each service area. The Chowchilla subbasin has roughly 145,000 irrigated acres, with about 100,000 acres receiving surface water from three water districts, each of which has formed a GSA. We have about 1,200 irrigated acres that are part of the Delta-Mendota subbasin and that don't receive surface water.

The irrigated areas that are outside the water district or irrigation district service areas are called "white areas." They have no access to surface water and depend entirely on groundwater. In the white areas, the county serves as the GSA, which makes the Board of Supervisors the governing body. One thing that is unique about Madera County is that all the white areas are managed by the county - in other counties, at least some of those areas are covered by water-district GSAs.

My role in the SGMA process is to advocate for farmers and agricultural landowners, to make sure that their interests are taken into consideration and adequately represented. The subbasins have regular coordination meetings of the GSAs in their boundaries. The GSAs, including the county GSA, generally schedule their GSA board meetings to coincide with their

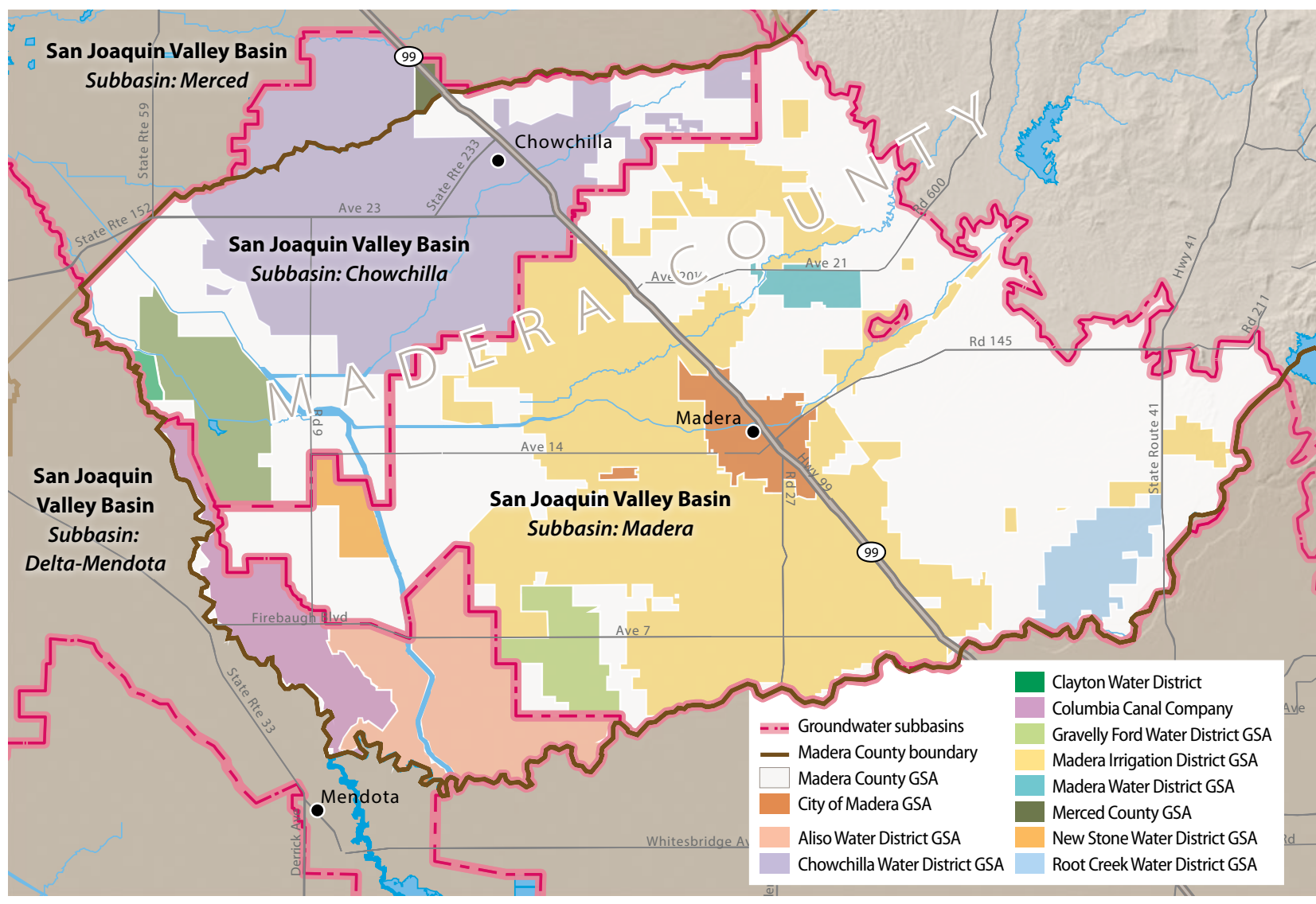


regular board meetings, saving some time, but still, it's a lot of water meetings.

The GSAs and the county are now working on developing GSPs. An analysis of the data gaps has been done, and consultants have been hired to determine what the sustainable yield is in each basin and create GSPs that take into account drought, average and wet years. There is still a lot of work to do.

As far as support from the state - I think they've been really good. You go and you have questions - and maybe they don't have everything in place, and there aren't defined responses yet, but they've tried very hard to lead me in the right direction or provide me with as much information as they can. The biggest hurdle for everyone is that SGMA implementation is an ongoing thing - it's been building, with the rules and guidance coming out slowly but surely.

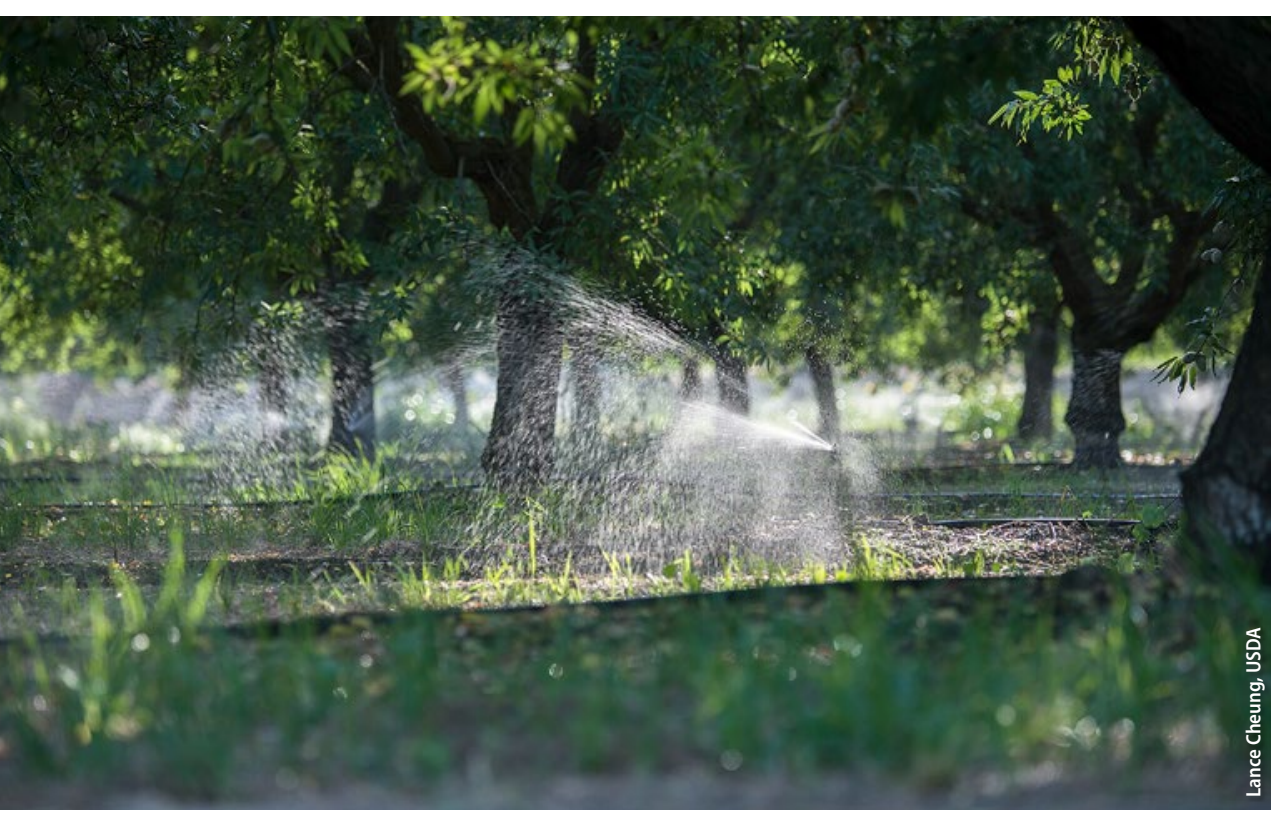

Irrigation in an almond orchard. Almonds are the leading crop in Madera County, with the 2016 harvest valued at $\$ 593$ million.

\section{Do you feel agriculture's interests are being considered fairly in the SGMA implementation process in your region?}

Overall, I would say yes. In Madera County, agriculture is the driving force of the economy, and all of the water districts that have formed GSAs are primarily agricultural water suppliers.

My main concern in Madera County is the white areas that don't receive surface water and are governed by the Board of Supervisors.

There has been a history of conflict over water for agriculture versus water for urban development in the county. On the east side of the county in particular, there's a lot of planned development. One case that people often bring up, is when the county Board of Supervisors approved a plan for 3,000 new homes that would be entirely dependent on groundwater, and then at their next meeting they proposed a moratorium on new agricultural wells. That moratorium didn't pass (and the housing developer later agreed to limits on groundwater extraction), but there's generally just a concern that the county may not represent the farmers well when those issues come up again. Unfortunately, ag will always be outvoted at election time, as municipal water users significantly outnumber ag land owners. Though I will say that currently we have a good board, all of whom are pretty mindful of agriculture.

\section{Do you think growers in Madera County are really confronting what a future with less groundwater extraction will look like?}

The conversations are definitely happening, though there hasn't really been any movement yet.

In the Chowchilla subbasin, the GSAs have said that the last thing they want to do is take land out of production, which I think is a common goal throughout the entire county. Everyone is looking for solutions, trying to be creative. In a lot of areas, landowners went above and beyond last winter to recharge as much groundwater as they possibly could. Conversations are also happening about ways to set up some sort of water credit or exchange system.

But, it's in the back of everyone's mind that some land is going to have to be fallowed. There's going to be an allocation set, and there's not going to be enough water to go around.

\section{Closing thoughts?}

I think it's just important that stakeholders remain engaged, and for the governing bodies to understand the importance of listening to stakeholders. We've had a lot of bumps in the road to get to where the county, the GSA governing body for much of the county, hears our voice. At the end of the day, municipal users will always outvote ag water users. Being engaged, having a voice, is still so important.

Also, I still get some farmers that tell me they're just now hearing about SGMA, or that they don't understand it. The other day somebody told me that they were thinking about putting in a permanent crop, and I asked about their source of water, and they said, "We have wells, we're OK." But those are the first people that are going to be subject to the regulations! So, I can't stress enough the importance of being engaged and asking questions. CA 